\title{
EFFECTIVENESS OF AL-BARQY METHOD IN IMPROVING THE ABILITY TO READ ARABIC BRAILLE ON STUDENTS IN GRADE 3 AT SDLB PUTRAMANUNGGAL GOMBONG
}

\section{Budiono}

\author{
SLB ABC Putramanunggal Gombong \\ budionoputracilacap@gmail.com
}

\section{Article History}

accepted 30/09/2018

approved 12/10/2018

published 30/10/2018

\section{Keywords}

effectiveness, Al-Barqy

method, reading ability

\begin{abstract}
This study aims to determine the effectiveness of Al-Barqy method to improve the ability to read Arabic braille on students with visual impairments in grade 2 at SDLB Putra Manunggal Gombong, Kebumen. This research is a classroom action research with 3 students of SDLB Putra Manunggal Gombong as the research subjects. This study consisted of 2 cycles that each cycle has 2 times of meetings. The utilized instruments were test sheet, interview sheet, and observation sheet. Triangulation techniques was used to validate the data. The results showed that: 1) the Al-Barqy method was effective in improving students ability to read Arabic braille letters that achieved a good category; 2) the understanding of read Arabic braille of SDLB students was increased through Al-Barqy method. They achieved an average value in the first cycle by number 70,22 with $66,67 \%$ learning completeness whereas in the second cycle was 77,56 with $100 \%$ learning completeness.
\end{abstract}

Social, Humanities, and Education Studies (SHEs): Conference Series https://jurnal.uns.ac.id/shes

p-ISSN 2620-9284 e-ISSN 2620-9292 


\section{PENDAHULUAN}

Kemampuan membaca menjadi salah satu kemampuan dasar yang harus dimiliki oleh peserta didik sekolah dasar selain kemampuan menulis. Membaca menjadi aktivitas yang penting dikarenakan menjadi kemampuan utama dalam aktivitas yang lain. Mutaqien (2017) menjelaskan bahwa kegiatan membaca merupakan proses berpikir yang perlu dilatih secara kontinyu dan tidak terjadi secara otomatis. Dilanjutkan bahwa dalam merangsang kecerdasan bahasa (linguistik) dapat dilakukan dengan memberikan stimulan kepada anak dengan cara melakukan sesi tanya jawab dalam pembelajaran, menunjukkan gambar, mendengarkan rekaman, dan menceritakan pengalaman/aktivitas sehari-hari. Mengajarkan anak untuk membaca, diperlukan kesabaran dan motivasi yang besar bagi guru karena memberikan manfaat yang sangat besar bagi ana. Melalui membaca, dapat mengembangkan pemahaman anak dalam hubungan antara bahasa lisan dan simbol tertulis serta memudahkan anak mengenali sebuah kalimat yang ada dalam tulisan sehingga peserta didik mampu mencerna maksud dari tulisan tersebut. Oleh sebab itu, kemampuan membaca diharapkan dapat dikembangkan sejak dini terutama kemampuan anak dalam membaca Alquran bagi yang beragam Islam.

Ishak (2016) menyebutkan bahwa Alquran merupakan kitab suci bagi semua Muslim yang mencakup semua aspek kehidupan. Ramli, dkk (2017) menjelaskan perintah membaca Alquran adalah tanggung jawab bagi semua muslim, bahkan belajar Alquran adalah fardhu-ain bagi setiap muslim individu untuk bisa dan mahir membaca Alquran, bahkan lebih baik lagi adalah sampai memahami dan mempraktikkan. Salah satu kompetensi dasar siswa sekolah dasar kelas III pada mata pelajaran Pendididikan Agama Islam (PAI) adalah siswa mampu membaca kalimat dalam Alquran yaitu dengan indikator pencapaian adalah melafalkan huruf-huruf Alquran melalui kalimat dengan benar. Siregar (2018) menyatakan bahwa dalam belajar Alquran terutama belajar baca tulis Alquran mencakup beberapa aspek yaitu aspek mengenal, merangkai, dan melafazhkan Alquran dengan benar sesuai dengan makhraj dan tajwid. Termasuk juga didalamnya masalah seni membaca dengan irama yang menjadikan bacaan Alquran terdengar indah. Dijelaskan juga bahwa kemampuan membaca Alquran mesti mengetahui, mengenal, dan merangkai huruf-huruf hijaiyyah sebagai huruf Arab sekaligus huruf Alquran. Sehingga dapat jelaskan bahwa kemampuan membaca Alquran dapat diartikan sebagai berikut: 1) kemampuan mengenal, merangkai dan membunyikan huruf dan harkat dengan benar; 2) kemampuan membaca huruf ketika berhubungan dengan huruf sesudahnya disesuaikan dengan hukumnya; 3) kemampuan membedakan bacaan panjang dan bacaan pendek; dan 4) mengetahui dimana dapat berhenti dan darimana dimulai apabila bacaan akan dilanjutkan (Siregar, 2018).

Kemampuan membaca Alquran yang paling utama adalah pengenalan makhraj dan tajwid dengan tepat dan benar. Namun pada kenyataanya, selama proses pembelajaran guru masih cenderung menggunakan metode konvensional sehingga mengakibatkan pembelajaran menjadi monoton dan kurang menyenangkan. Pembelajaran yang berpusat pada guru memberikan dampak yang kurang bagus bagi perkembangan peserta didik, khususnya dalam hal kemampuan membaca huruf Arab braile. Hal ini dapat dilihat dari hasil kemampuan membaca huruf Arab braile peserta didik yang masih jauh dari batas KKM. Kurangnya kemampuan membaca menunjukkan bahwa peserta didik di SLB Putra manunggal Gombong masih banyak mengalami kekeliruan dalam membaca huruf Arab Braille. Selain itu, masih banyak yang belum konsisten bacaan fathah, kashroh, dan dhomah pada suatu bacaan. Berdasarkan permasalahan tersebut, perlu adanya inovasi dalam pembelajaran yang salah satunya menggunakan metode membaca Alquran Al-Barqy. 
Metode Al-Barqy merupakan metode belajar membaca Alquran yang ditemukan oleh Muhadjir Sulthon pada tahun 1965. Astuti (2013) menjelaskan bahwa metode AlBarqy disebut juga dengan metode anti lupa karena struktur yang apabila pada saat peserta didik lupa dengan huruf-huruf atau suku kata yang telah dipelajari, maka akan dengan mudah mengingat kembali tanpa bantuan guru. Metode Al-Barqy dirancang dengan menggunakan bahasa yang lebih dekat dengan anak yaitu membentuk kata lembaga seperti ada-raja, maha-kaya, kata-wana, sama-laba. Beberapa prinsip yang harus diperhatikan dalam pembelajaran metode Al-Barqy yaitu harus diajarkan secara gradual, dibaca langsung tanpa dieja, tidak diperkenalkan nama huruf hijaiiyaj, dituntut keaktifan siswa bersifat praktis (diajarkan langsung dalam bentuk praktik), dan sederhana (diawali dengan menerangkan huruf-huruf yang mudah diucapkan). Sedangkan syarat dalam pembelajaran Al Barqy ada lima, yaitu: 1) pendekatan dengan menggunakan 4 buah kata lembaga (ada-raja, maha-kaya, kata-wana, samalaba); 2) sistem analitik sintetik (memisahkan kata seperti ADA dan RAJA); 3) menggunakan teknik menyanyi (menyanyi huruf kata lembaga); 4) bercerita, menceritakan untuk memberi kesan pada peserta didik agar mengingat empat buah kata lembaga; dan 5) belajar konsentrasi.

Sulthon (2013: 17) menyebutkan kelebihan metode Al-Barqy yaitu metode ini menjanjikan bagi seseorang yang tidak kenal huruf hijaiyyah sama sekali bisa berubah minimal dengan pembelajaran 200 menit menjadi mampu membaca Alquran. Pransiska (2015) mengemukakan bahwa metode Al-Barqy terasa lebih dekat dengan bahasa anak-anak yaitu dengan menyesuaikan yang biasa dilafalkan anak-anak, yaitu a-da-ra-ja, ma-ha-ka-ya, ka-ta-wa-na, sa-ma-la-ba. Huliyah (2017) menjelaskan beberapa kelebihan dari metode Al-Barqy, yaitu: 1) menggunakan sistem 8 jam, artinya hanya dengan waktu 8 jam peserta didik dapat membaca dan menulis huruf Alquran; 2) praktis untuk segala umur; 3) menggunakan metode yang aktual yaitu SAS (Struktur Analitik Sintetik) yang memudahkan peserta didik belajar Alquran; 4) memperhatikan pendekatan, sistematika dan teknik dalam pembelajaran; 5) cepat dapat membaca huruf sambung; 6) bukunya dilengkapi teknik imlak yang praktis dan teknik menulis khat, serta dilengkapi dnegan biku latihan menulis Al-Barqy (LKS); 7) tidak membosankan karena ada teknik-teknik yang akurat dan menarik seperti menyanyi, permainan, dan lain-lain; dan 8) sangat cepat jika dipakai secara massal.

Telah banyak penelitian yang menggunakan metode Al-Barqy dalam meningkatkan kemampuan membaca Alquran terutama bagi peserta didik berkebutuhan khusus. Wijayanti (2010) menghasilkan temuan bahwa menggunakan metode Al-Barqy mampu meningkatkan kemampuan membaca huruf hijaiyyah siswa tunarungu wicara serta meningkatkan keaktifan dan perhatian siswa dalam pembelajaran. Selanjutnya, hasil penelitian Astuti (2013) menghasilkan bahwa metode Al-Barqy mampu meningkatkan pemahaman bacaan Quran anak-anak Attention Deficit Disorder (ADD) serta terjadi peningkatan pada fokus belajar siswa. Berdasarkan penjelasan tersebut, penggunanaan metode Al-Barqy diharapkan efektif dapat meningkatkan kemampuan membaca Alquran siswa tunanetra.

\section{METODE}

Penelitian ini merupakan penelitian tindakan kelas (PTK) yang dilaksanakan dalam 2 siklus yang masing-masing terdiri dari 2 pertemuan. Setiap siklus terdiri dari tahap perencanaan, pelaksanaan, observasi, dan refleksi. Subjek penelitian adalah siswa kelas III di SDLB Putra Manunggal Gombong, Kebumen yang berjumlah 3 siswa. Teknik pengumpulan data melalui observasi, interview, dan tes. Validitas data menggunakan teknik triangulasi. Gambar 1 adalah desain penelitian tindakan kelas pada penelitian ini. 


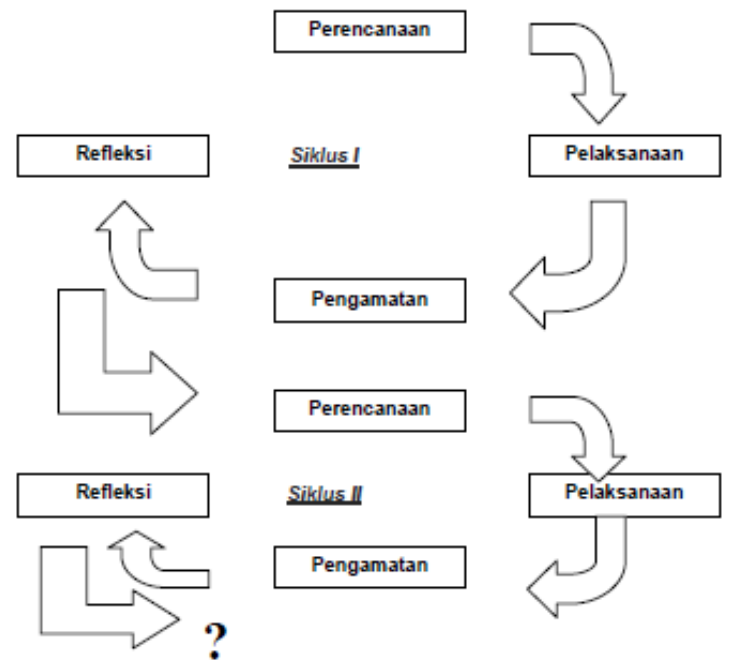

\section{Gambar 1.Desain Penelitian Tindakan Kelas}

(Sumber: Arikunto, 2010)

Untuk mengetahui hasil tes kemampuan membaca tulisan arab siswa dikategorikan seperti pada tabel 1.

\section{Tabel 1.Kriteria Kemampuan Membaca Tulisan Arab}

\begin{tabular}{ccc}
\hline No & Rentang Nilai & Kriteria \\
\hline 1 & $80-100$ & Sangat Baik \\
2 & $66-79$ & Baik \\
3 & $56-65$ & Cukup \\
4 & $40-55$ & Kurang \\
5 & $\leq 39$ & Gagal \\
\hline & (Diadaptasi dari Arikunto, 2009)
\end{tabular}

Data keefektifan diperoleh dari data pretest dan postest peserta didik. Untuk mengolah data kefektifan menggunakan persamaan 1 (Arikunto, 2006)

$$
\bar{X}=\frac{\sum x}{\sum N}
$$

Berdasarkan pengolahan data keefektifan selanjutnya diinterpretasikan tingkat keefektifannya. Metode Al-Barqy dikatakan efektif jika rata-rata kemampuan membaca tulisan arab peserta didik mencapai $\geq 70$. Jika kurang dari 70 , maka dikatakan tidak efektif. Artinya, jika rata-rata kemampuan membaca tulisan arab peserta didik mencapai $\geq 70$, metode Al-Barqy yang digunakan dapat dikatakan memiliki peran yang efektif dalam meningkatkan kemampuan membaca tulisan arab. Kriteria keefektifan yang digunakan sebagai pedoman dapat dilihat pada tabel 2 .

Tabel 2.Kriteria Kefektifan Penggunaan Metode Al-Barqy

\begin{tabular}{cc}
\hline Skor Keefektifan & Kriteria \\
\hline $85-100$ & Sangat efektif \\
$70-84$ & Efektif \\
$50-69$ & Kurang efektif \\
$0-49$ & Tidak efektif \\
\hline
\end{tabular}


(Sumber Didapatasi dari: Yamasari, 2010)

\section{HASIL DAN PEMBAHASAN}

Sebelum pembelajaran menggunakan metode Al-Barqy, guru melakukan pra tindakan untuk mengetahui kemampuan awal membaca arab braille pada siswa yang dapat dilihat pada tabel 3.

Tabel 3. Hasil tes Kemampuan Awal Membaca Arab Braille

\begin{tabular}{ccc}
\hline Siswa ke- & Nilai Kemampuan Awal & Kriteria \\
\hline 1 & 30 & Gagal \\
2 & 40 & Kurang \\
3 & 35 & Gagal \\
Rata-Rata & $\mathbf{3 5}$ & Gagal \\
\hline
\end{tabular}

Berdasarkan hasil nilai kemampuan awal seperti pada tabel 3, seluruh siswa belum mampu membaca arab Braille dengan lancar dan benar, terutama bagian tanda baca suatu bacaan. Mengacu pada hasil kemampuan awal tersebut, diperlukan tindakan lanjutan untuk mendapatkan hasil yang lebih baik yaitu menggunakan metode Al-Barqy. Metode Al-Barqy yang digunakan menggunakan langkah-langkah yang diadaptasi dari Pransiska (2010), yaitu:

a. Fase analitik, guru memberikan contoh bacaan yang berupa kata-kata lembaga. Kata lembaga tersebut merupakan struktur yang terdiri dari huruf-huruf hijaiyyah.

ADA RAJA - MAHA KAYA - KATA WANA - SAMA LABA

Guru membacakan kata lembaga tersebut kemudian diikuti oleh peserta didik berulang-ulang sampai hafal.

b. Fase Penulisan, guru memberikan contoh tulisan keempat kata lembaga tersebut sampai selesai kemudian siswa menuliskan ulang sampai benar secara berulangulang. Selanjutnya guru menyebutkan salah satu huruf dengan acak dan siswa menuliskan melalui papan reglet dengan cara guru mendikte dan siswa menulis sambil menyebutkan huruf yang ditulisnya berulang kali sampai hafal.

c. Fase Sintetis, guru memberikan sebuah tulisan dari gabungan kata lembaga tersebut dan meminta satu per satu siswa untuk membaca.

d. Fase pengenalan bunyi a-i-u, yaitu pengenalan terhadap tanda baca fathah, kashroh, dan dhomah.

e. Fase Pemindahan, yaitu pengenalan terhadap bacaan atau bunyi Arab yang sulit, maka didekatkan pada bunyi-bunyi Indonesia yang berdekatan, contoh: huruf $d z a l$ dengan pendekatan huruf dal dan huruf Syin dengan pendekatan huruf $\sin$.

f. Fase Pembacaan, yaitu guru memberikan contoh tulisan arab secara acak, kemudian meminta siswa untuk membaca satu per satu.

Pada siklus I materi yang disampaikan adalah mereview bacaan huruf hijaiyyah siswa dan penulisan huruf hijaiyyah serta pengenalan tanda baca fathah, kashroh, dan dhomah. Pemberian informasi jika huruf hijaiyyah yang diberikan tanda baca, maka dibaca beda sesuai dengan tanda baca yang digunakan. Contoh huruf alif jika diberi tanda baca fathah, maka dibaca a. Hasil tes kemampuan membaca tulisan Arab braille pada siklus I dapat dilihat pada tabel 4. 
Tabel 4. Hasil Tes Kemampuan Membaca Arab Braille Siklus I

\begin{tabular}{cccc}
\hline Siswa ke- & Aspek & Rata-Rata Nilai & Kriteria \\
\hline 1 & Membaca Huruf Hijaiyyah & 65 & Cukup \\
& Mengenal Harokat/Tanda & 65 & \\
Baca & 60 & \\
Membaca Kata & 63,34 & Baik \\
2 & Rata-Rata & 78 & \\
& Membaca Huruf Hijaiyyah & 78 & \\
Mengenal Harokat/Tanda & Baca & 75 & \\
& Membaca Kata & 77 & \\
& Rata-Rata & 70 & \\
& Membaca Huruf Hijaiyyah & & \\
& Mengenal Harokat/Tanda & 68 & \\
& Membaca Kata & 70,34 & \\
& Rata-Rata & &
\end{tabular}

Tabel 4 menunjukkan bahwa rata-rata kemampuan siswa membaca tulisan arab pada siklus I aspek membaca huruf hijaiyyah memperoleh nilai yang paling tinggi, sedangkan pada aspek membaca kata memperoleh nilai yang paling rendah. Pada siklus I, sebanyak 2 siswa $(66,67 \%)$ memperoleh ketuntasan dalam belajar, sedangkan 1 siswa masih belum memperoleh ketuntasan dalam belajar. Berdasarkan hasil observasi, siswa masih belum lancar membaca kata dengan tepat dan lancar serta masih ada siswa yang membaca dengan terbalik/salah tanda bacanya. Berdasarkan hasil analisis tersebut, diperlukan tindakan selanjutnya pada siklus II. Pada siklus II pembelajaran metode Al-Barqy selain menggunakan teknik lagu/menyanyi, guru juga menggunakan teknik bercerita dan memperbanyak quiz. Hasil nilai kemampuan siswa pada siklus II dapat dilihat pada tabel 5 .

Tabel 5. Hasil Tes Kemampuan Membaca Arab Braille Siklus II

\begin{tabular}{|c|c|c|c|}
\hline Siswa ke- & Aspek & Rata-Rata Nilai & Kriteria \\
\hline 1 & Membaca Huruf Hijaiyyah & 73 & \multirow[t]{4}{*}{ Baik } \\
\hline & $\begin{array}{c}\text { Mengenal Harokat/Tanda } \\
\text { Baca }\end{array}$ & 75 & \\
\hline & Membaca Kata & 70 & \\
\hline \multicolumn{2}{|r|}{ Rata-Rata } & 72,67 & \\
\hline 2 & Membaca Huruf Hijaiyyah & 80 & \multirow[t]{4}{*}{ Sangat Baik } \\
\hline & $\begin{array}{c}\text { Mengenal Harokat/Tanda } \\
\text { Baca }\end{array}$ & 85 & \\
\hline & Membaca Kata & 80 & \\
\hline \multicolumn{2}{|r|}{ Rata-Rata } & 81,67 & \\
\hline \multirow[t]{3}{*}{3} & Membaca Huruf Hijaiyyah & 80 & \multirow[t]{4}{*}{ Baik } \\
\hline & $\begin{array}{c}\text { Mengenal Harokat/Tanda } \\
\text { Baca }\end{array}$ & 75 & \\
\hline & Membaca Kata & 80 & \\
\hline & Rata-Rata & 78,33 & \\
\hline
\end{tabular}

Berdasarkan tabel 5, kemampuan siswa dalam membaca tulisan arab menunjukkan kategori baik dengan jumlah $100 \%$ siswa telah memperoleh batas 
ketuntasan belajar. Berdasarkan hasil observasi, pada siklus II siswa lebih aktif dalam mengikuti pembelajaran dan bisa lebih fokus untuk memperhatikan guru. Hasil wawancara dengan siswa, siswa senang dengan pembelajaran menggunakan metode Al-Barqy dikarenakan pembelajarannya lebih menyenangkan dengan diselingi lagulagu dan cerita dari guru. Sedangkan metode quiz mampu menyemangati siswa untuk mengerjakan dengan cepat dan benar. Siswa merasa tertantang untuk menyelesaikan tugas dari guru. Selanjutnya, reward yang diberikan oleh guru juga memberikan dampak positif dalam membangun kepercayaan diri peserta didik. Meskipun jika masih ada siswa yang masih kurang tepat dalam menjawab, guru dengan pelan-pelan dan sabar membimbing siswa untuk terus bisa mengerjakan.

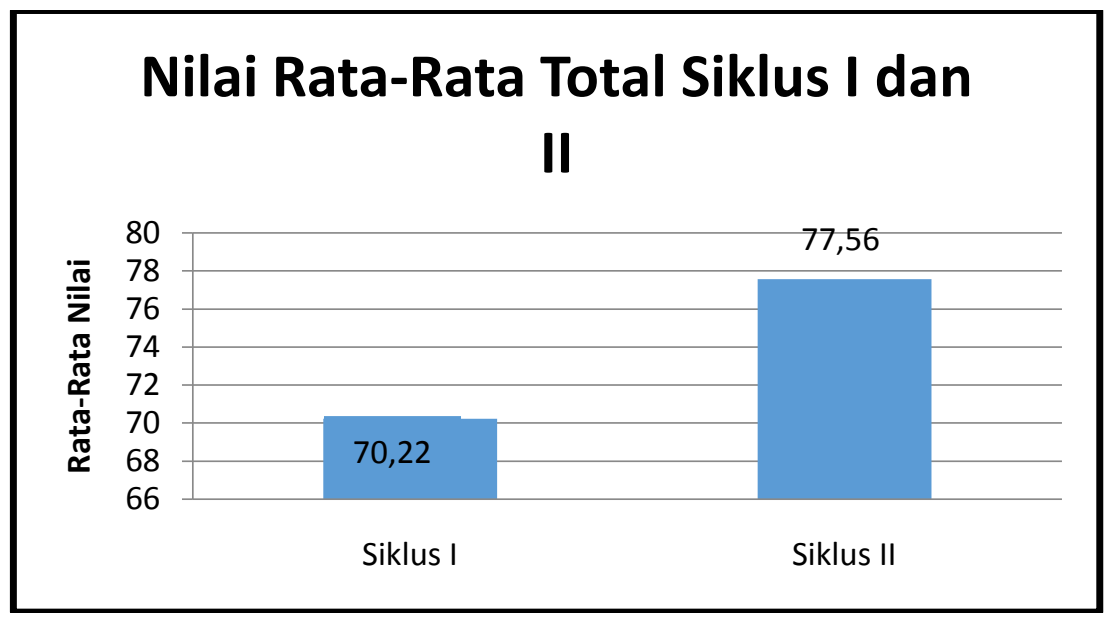

Gambar 2. Nilai rata-rata total siklus I dan II

Gambar 2 menunjukkan bahwa rata-rata nilai secara keseluruhan pada siklus I dan II adalah 70,22 dan 77, 57 yang artinya metode Al-Barqy efektif mampu meningkatkan kemampuan membaca tulisan arab braille pada siswa kelas III SLB. Hal ini sejalan dengan penelitian Wijayanti (2010) yang menghasilkan temuan bahwa metode Al-Barqy dapat meningkatkan kemampuan membaca huruf hijaiyyah bagi siswa tunarungu. Selain mampu meningkatkan kemampuan membaca, keaktifan dan perhatian siswa selama proses pembelajaran juga mengalami peningkatan melalui metode Al-Barqy. Idayani (2018) menjelaskan bahwa keaktifan siswa selama proses belajar mengajar merupakan salah satu indikator adanya keinginan atau motivasi siswa untuk belajar. Melalui keaktifan ini, siswa akan lebih semangat dalam mengerjakan tugas dari guru, mau bertanya kepada guru dan menjawab pertanyaan dari guru, serta senang jika diberikan tugas. Aktivitas yang muncul dari siswa akan membentuk pengetahuan dan keterampilan yang akana mengarah pada peningkatan prestasi. Peningkatan prestasi dapat diartikan dengan peningkatan kemampuan siswa dalam membaca tulisan arab braile.

\section{SIMPULAN}

Hasil penelitian menunjukkan bahwa: 1) metode Al-Barqy efektif meningkatkan kemampuan membaca tulisan arab braille dengan kategori baik; 2) peningkatan pemahaman membaca tulisan arab braille siswa SDLB melalui metode Al-Barqy dengan nilai rata-rata pada siklus I adalah 70,22 dengan ketuntasan belajar sebesar $66,67 \%$, dan nilai rata-rata pada siklus II adalah 77,56 dengan ketuntasan belajar sebesar $100 \%$. Rekomendasi dalam penelitian ini guru diharapkan lebih banyak 
menggunakan teknik-teknik yang lebih bervariasi dalam metode Al-Barqy agar pembelajaran lebih menyenangkan. Namun, selain metode Al-Barqy, metode tahsin dan ABAHATA Al-Jabari dapat digunakan sebagai metode pembelajaran membaca tulisan arab/Alquran bagi anak berkebutuhan khusus.

\section{DAFTAR PUSTAKA}

Arikunto, S. 2009. Manajemen Penelitian. Jakarta: Rineka Cipta.

Arikunto, S. 2010. Prosedur Penelitian Suatu Pendekatan Praktek. Jakarta: Rineka Cipta.

Astuti, R. (2013). Peningkatan Kemampuan Membaca Alquran Pada Anak Attention Deficit Disorder Melalui Metode Al-Barqy Berbasis Applied Behavior Analysis. Jurnal Pendidikan Usia Dini. 7 (2), 351-366.

Huliyah, M. (2017). Metode Al-Barqy dalam Perspektif Multiple Intelligence. Geneologi PAI : Jurnal Ilmiah Bidang Pendidikan Agama. 3 (1), 23-32.

Idayani, Ni P. (2018). Pengaruh Pembelajaran Kooperatir Model STAD Terhadap Keaktifan dan Hasil Belajar IPA Kelas VII SMP. Journal of Education Action Research. 2 (1), 30-39.

Ishak, H. (2016). Methods of Teaching al-Quran to the Hearing Disability Children. Tinta Artikulasi Membina Ummah Journal. 2 (1), 33-39.

Mutaqien, Z. (2017). The Learning Method of Alquran for Early Childhood. International Conference on Education Universitas Muhammadiyah Purworejo. 1 (1), no page

Pransiska, T. (2015). Fenomena Konstruktivistik dalam Metode Al-Barqy dalam Pembelajaran Alquran: Perspektif Pskolinguistik. Hikmah Journal of Islamic Studies. XI (2), 31-46.

Ramli, A.J., Kamaludin, M., Hamzah, M.I. (2017). Implementation and Development of Qur'an Learning Method in Malaysia and Indonesia: An Analysis. Khalifa Journal of Islamic Education. 1 (1), 51-78.

Siregar, A. (2018). Penerapan Metode Iqro' dan Pengaruhnya Terhadap Kemampuan Membaca Alquran Murid MDA Muhammadiyah Bonan Dolok. Al-Muaddib: Jurnal ilmu-IImu Sosial dan Keislaman. 1 (1), 1-28.

Sulthon, M. (2013). Metode Cepat Al-Barqy; Jalan Pintas Metode Belajar Membaca alQur'an Sistem 200 Menit. Surabaya: CV Pena Ameen.

Wijayanti, E.M. (2010). Penggunaan Metode Al-Barqy Untuk Membaca Huruf Hijaiyah Pada Anak Tunarungu Wicara Kelas VIII SMP di SLB B YRTRW Surakarta. Skripsi: Universitas Sebelas Maret.

Yamasari. (2010). Pengembangan Media Pembelajaran Matematika Berbasis ICT yang Berkualitas. Makalah disajikan pada Seminar Nasional Pascasarjana X-ITS, Surabaya. 